\title{
A Creative Indirect Spectrophotometric Determination of Naproxen
}

\author{
Thura Z. Al-Sarraj \\ Hana Sh. Mahmood \\ Department of Chemistry/College of Science/ University of Mosul
}

(Received 6/ 6/ 2018 ; Accepted $3 / 12$ / 2018)

\begin{abstract}
A New, sensitive spectrophotometric method for determination of Naproxen (Nap) has been proposed. The method is based on a modification of Naproxen into a hydroxy analog (mNap). The modified compound is coupled with the diazotized p-aminobenzoic acid (PABA) in alkaline medium, the resulting orange azo dye exhibit a maximum absorption at $500 \mathrm{~nm}$. Beer's law is obeyed over the concentration range from 10 to $650 \mu \mathrm{g} / 20 \mathrm{ml}$, (i.e. 0.5-32.5 $\mu \mathrm{g} / \mathrm{ml}$ ) with a good sensitivity (molar absorptivity $2.14 \times 10^{4} \mathrm{l} \cdot \mathrm{mol}^{-1} \cdot \mathrm{cm}^{-1}$ ), good precision (RSD\% better than $\pm 1.93 \%$ ) and high accuracy (relative error \% better than $0.43 \%$ ), Sandell's sensitivity index is $0.0107 \mu \mathrm{g} . \mathrm{cm}^{-2}$ and the limit of detection (LOD) is $0.024 \mu \mathrm{g} / \mathrm{ml}$ and the limit of quantitation (LOQ) is $0.082 \mu \mathrm{g} / \mathrm{ml}$. The method has been applied successfully for determination of Naproxen in dosage forms after extraction of the active ingredient.
\end{abstract}

Keywords: Naproxen, spectrophotometric, modification reaction, diazotized p-aminobenzoic acid, extraction, Creative.

\section{طرقةطيفية مستحثة غيرمبلثرة لقحير النابروكسين}

\section{المالخص}

مُ اقتراحطريقة طيفية جيية ومسلسة لقحير النابروكسين في مستحضراته الصيدلانية بعد تحوير النابروكسين اله مماثله الذي يحتوي على مجموعة هيدروكسل ومن ثم اقترانه في المحط القاعدي مع الكلثف حلمض بارا لمينو البنزويك

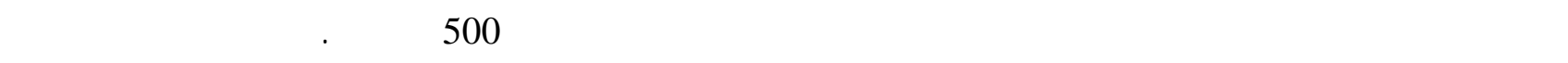

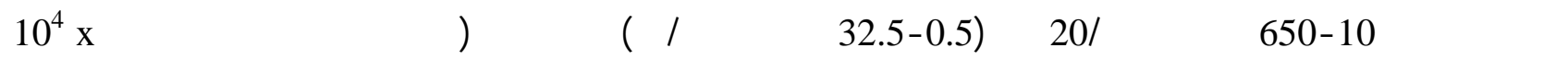

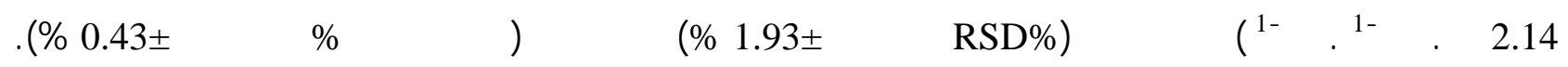

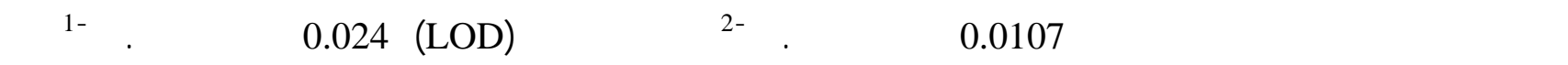
القدير(LOQ) 0.082 مايكروغرله aل -1. م طبيق الطريقة بنجاح في نقدير النابروكسين في مستحضراته الصيدلانية بعد الستخلاص المادة الفعالة.

الكاملت الدالة: نابروكسين،طريقةطيفة، تفاعل تحوير، حلمض بارا لمينو البززويك المؤزوت، لستخلاص، مستحثة.

Naproxen (Nap) is an analgesic, anti-inflammatory drug with antipyretic activities largely related to inhibition of prostaglandin synthesis (Karch, 2010), this drug is used more and more frequently because it blocks RNA-binding groove of nucleoprotein of virus and may have antiviral activity against influenza (Lejal et al.,2013).

Naproxen is (S)-2-(6-methoxynaphthalen-2-yl)-(+) propanoic acid $\mathrm{C}_{14} \mathrm{H}_{14} \mathrm{O}_{3}(230.259 \mathrm{~g} / \mathrm{mol})$ with the chemical structure as below (Acomoffat et al.,2005). 
<smiles>COc1ccc2cc(C(C)C(=O)O)ccc2c1</smiles>

\section{Naproxen structure}

A few methods for quantitative determination of Naproxen have been reported, these including HPLC (Wahbi et al.,2009) (Tashtoush and Al-Taani, 2003) (Muneer et al., 2017), RPHPLC (Pansara et al., 2013), LC-MS (Veeragoni et al., 2016), electrochemical method (Soltani et al., 2018), Ion selective electrode (Lenik et al., 2002), chemiluminescence (Yinhuan and Jiuru, 2006), Conductometric (Alhazmiand and Al Bratty, 2017), While other papers report a spectrophotometric assay of Naproxen at uv region (Nijhu et al.,2011) (Maheshwari et al., 2010) (Sloka et al.,2011) (Jain et al.,2011). A colorimetric assay of naproxen tablets based on chemical derivatization with the chromogenic reagent 4-carboxyl-2,6-dinitrobenzene diazonium ion was developed. The optimal reaction time was found to be $5 \mathrm{~min}$ at $30{ }^{\circ} \mathrm{C}$ after vortex mixing of the drug/reagent mixture for $10 \mathrm{~s}$. The optimal analytical wavelength was found to be $470 \mathrm{~nm}$ (Idowu et al., 2009).

Naproxen was determined by formation of ion-pair complex with bromophenol blue,the colored product was measured at $432 \mathrm{~nm}$ (Keyhanian et al.,2014), another ion-pair procedure based on reaction between Naproxen with two sulfophthalein acid dyes, namely bromocresol green and bromothymol blue (Alizadeh and Keyhanian, 2015).

The aim of this work is determination of naproxen by indirect spectrophotometric method after modification of Nap to hydroxyl analog, then coupling with diazotized p-aminobenzoic acid (PABA).

\section{Apparatus}

\section{EXPERIMENTAL}

All spectral and absorbance measurement were performed on double-beam Jasco V-630 spectrophotometer with $1.0 \mathrm{~cm}$ matched quartz cells. $\mathrm{pH}$ measurements were performed using HANNA $301 \mathrm{pH}$ meter, BEL balance was used for weight measurements, reflux was utilized by electrothermal heater and stirring was utilized by Wisd stirrer.

\section{Reagents}

All chemicals used were of analytical grade.

-Modification reaction of Naproxen: $0.04 \mathrm{ml}$ of pure Naproxen (9.2 g) was mixed with $25 \mathrm{ml}$ hydrobromic acid (48\%) and $25 \mathrm{ml}$ acetic acid , the mixture was refluxed for 1.5 hour and then was cooled ,diluted with $25 \mathrm{ml}$ distilled water, filtrated, dryed and finally was recrystallized using ethanol to produce a pink solid crystal with melting point (190-191 C) (Al-Hamdany, 2009).

-Modified Naproxen (mNap) (100 $\mathbf{\mu g} / \mathbf{~ m l})$ : It was prepared by dissolving $0.0100 \mathrm{~g}$ of mNap in 2 $\mathrm{ml}$ ethanol and the volume was completed to $100 \mathrm{ml}$ with distilled water in a volumetric flask. The solution was then transferred to a dark bottle and it is stable for at least one month.

-Sodium Nitrite $\left(\mathrm{NaNO}_{2}\right)$ 1\%: This solution was prepared by dissolving $1.0 \mathrm{~g}$ of $\mathrm{NaNO}_{2}$ in distilled water and the volume was completed to $100 \mathrm{ml}$ in a volumetric flask.

-Sulphamic acid 3\%: This solution was prepared by dissolving $3.0 \mathrm{~g}$ of sulphamic acid in distilled water and the volume was completed to $100 \mathrm{ml}$ in a volumetric flask.

- p-Aminobenzoic acid $\left(2 \times 10^{-3} \mathbf{M}\right)$ : It was prepared by dissolving $0.0548 \mathrm{~g}$ of PABA in $200 \mathrm{ml}$ distilled water in a volumetric flask. 
- Phosphoric acid $\mathrm{H}_{3} \mathrm{PO}_{4}$ (1M): This solution was prepared by dilution of $6.84 \mathrm{ml}$ of the concentrated phosphoric acid (14.6 M) solution to $100 \mathrm{ml}$ with distilled water in a volumetric flask.

- Sodium hydroxide solution (1M): This solution was prepared by appropriate dilution of the concentrated solution (Fluka) with distilled water to $1000 \mathrm{ml}$ in a volumetric flask and then transferred to a plastic bottle.

-Pharmaceutical preparation (Naproxen Tablet (500 $\mathbf{~ m g ) ) : ~} 10$ tablets of Nap was grinded to a fine particles and a weight equivalent to one tablet, was dissolved in $3 \mathrm{ml}$ ethyl acetate and $1 \mathrm{ml}$ $\mathrm{HCl}(3 \mathrm{M})$, two layer was separated, the organic layer was transferred to another tube and extraction was repeated 3 times, $1 \mathrm{ml}$ of saturated solution of $\mathrm{NaCl}$ was added to organic layer and sufficient amount of sodium sulphate was added after separation, The layer was left on air for drying, the melting of dried product improve the formation of Nap hydroxy analog and proceed as mentioned above in modification of Nap. (Ka Le; project).

\section{Chemical reactions}

1-Modification reaction of naproxen: This step involves a conversion of Nap into a hydroxy analog (mNap) using hydrobromic acid in presence of acetic acid at a certain amounts.<smiles>COc1ccc2cc(C(C)C(=O)O)ccc2c1</smiles>

2-Diazotization reaction of PABA: In this step PABA is treated with an excess amount of nitrite in acidic medium to form the corresponding diazonium salt.<smiles>Nc1ccc(C(=O)O)cc1</smiles>

PABA
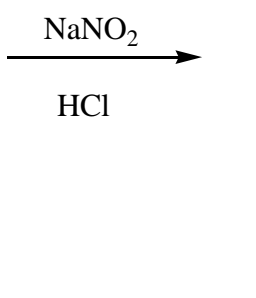<smiles>N#[N+]c1ccc(C(=O)O)cc1</smiles>

Diazotized PABA

3- Excess of nitrite can be removed by sulphamic acid

$$
\begin{aligned}
& \mathrm{HNO}_{2}+\mathrm{NH}_{2} \mathrm{SO}_{3} \mathrm{H} \longrightarrow \mathrm{N}_{2} \uparrow+\mathrm{H}_{2} \mathrm{O}+\mathrm{H}_{2} \mathrm{SO}_{4} \\
& \text { Excess } \\
& \text { Salphamic acid }
\end{aligned}
$$

4- Coupling reaction: The corresponding diazonium salt coupled with the modified Nap in alkaline medium to produce the colored azo dye. 
<smiles>CC(C(=O)O)c1ccc2cc(O)ccc2c1</smiles>

\section{Procedure and calibration graph}

The following reagents has been added in the following order: $2 \mathrm{ml}$ of $\left(2 \times 10^{-3} \mathrm{M}\right) \mathrm{p}$ aminobenzoic acid, $2 \mathrm{ml}$ of $\left(\mathrm{H}_{3} \mathrm{PO}_{4}\right), 1 \mathrm{ml}$ of $1 \% \mathrm{NaNO}_{2}, 0.5 \mathrm{ml}$ of $3 \%$ sulphamic acid, increasing volumes (0.1-6.5) $\mathrm{ml}$ of $100 \mu \mathrm{g} \cdot \mathrm{ml}^{-1}$ standard mNap solution and finally $2 \mathrm{ml}$ of $\mathrm{NaOH}(1 \mathrm{M})$, the volumes were completed to $20 \mathrm{ml}$ in a volumetric flasks with distilled water, the absorbances have been measured at $500 \mathrm{~nm}$ against blank solution. Fig. (1)

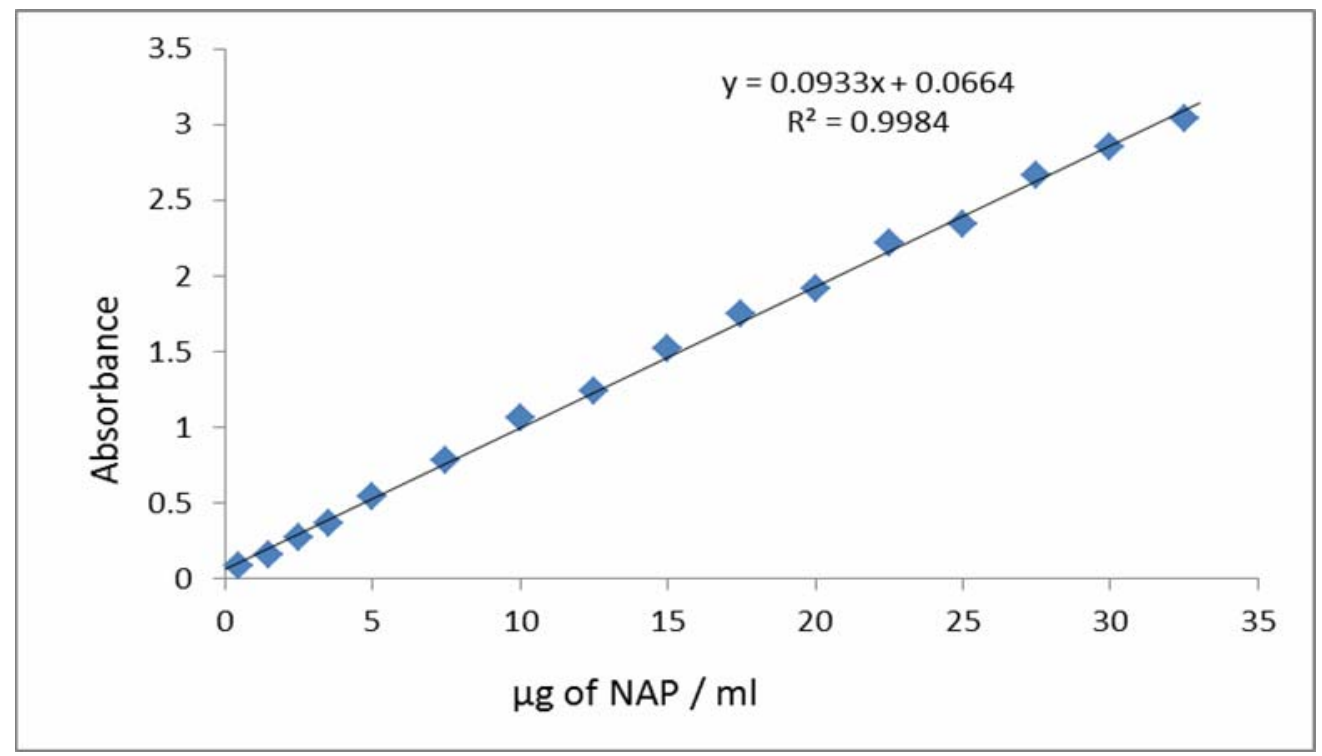

Fig. 1: Calibration graph of Naproxen

A linear calibration graph is obtained over the range 0.5-32.5 $\mu \mathrm{g}$ of mNap / ml (10-650 $\mu \mathrm{g} / 20$ $\mathrm{ml}$ ) with a molar absorptivity $2.14 \times 10^{4} \mathrm{l} \cdot \mathrm{mol}^{-1} \cdot \mathrm{cm}^{-1}$ and Sandell's sensitivity index $0.0107 \mu \mathrm{g} . \mathrm{cm}^{-2}$.

\section{Study of the optimum reaction conditions}

\section{Selection of acid and its amount}

Diazotization of PABA undergoes in acidic medium, therefore, effect of different amount of many acids on absorption intensity has been studied (Table 1).

\section{Table 1: Selection of acid and its amount}

\begin{tabular}{|c|c|c|c|c|c|}
\hline \multirow{2}{*}{ Acid used (1M) } & \multicolumn{5}{|c|}{ Absorbance/ ml of acid } \\
\cline { 2 - 6 } & $\mathbf{0 . 5}$ & $\mathbf{1 . 0}$ & $\mathbf{1 . 5}$ & $\mathbf{2 . 0}$ & $\mathbf{2 . 5}$ \\
\hline $\mathbf{H C l}$ & 0.259 & 0.225 & 0.184 & 0.137 & 0.073 \\
\hline $\mathbf{H}_{\mathbf{2}} \mathbf{S O}_{\mathbf{4}}$ & 0.236 & 0.226 & 0.220 & 0.218 & 0.212 \\
\hline $\mathbf{H N O}_{\mathbf{3}}$ & 0.285 & 0.278 & 0.278 & 0.271 & 0.270 \\
\hline $\mathbf{H}_{\mathbf{3}} \mathbf{P O}_{\mathbf{4}}$ & 0.205 & 0.255 & 0.390 & 0.537 & 0.360 \\
\hline $\mathbf{C H}_{\mathbf{3}} \mathbf{C O O H}$ & 0.201 & 0.274 & 0.480 & 0.089 & 0.040 \\
\hline
\end{tabular}


From (Table 1), $2 \mathrm{ml}$ of $\mathrm{H}_{3} \mathrm{PO}_{4}$ gives the maximum absorptions intensity of the colored product; therefore it is used for the following experiments.

\section{Effect of nitrite amount with time}

Between $0.1 \mathrm{ml}$ to $1.2 \mathrm{ml}$ of $\mathrm{NaNO}_{2}(1 \%)$ has been checked with a standing time from 0 to 5 min, the results are listed in (Table 2).

Table 2: Effect of nitrite amount with time

\begin{tabular}{|c|c|c|c|c|c|}
\hline \multirow{2}{*}{$\begin{array}{c}\text { ml of (1\% ) NaNO } \\
\text { solution }\end{array}$} & \multicolumn{5}{|c|}{ Absorbance / minute standing time } \\
\cline { 2 - 6 } & Immediatly & $\mathbf{1}$ & $\mathbf{2}$ & $\mathbf{3}$ & $\mathbf{5}$ \\
\hline $\mathbf{0 . 1}$ & 0.476 & 0.499 & 0.480 & 0.480 & 0.480 \\
\hline $\mathbf{0 . 3}$ & 0.504 & 0.520 & 0.509 & 0.504 & 0.504 \\
\hline $\mathbf{0 . 5}$ & 0.520 & 0.536 & 0.523 & 0.524 & 0.519 \\
\hline $\mathbf{0 . 7}$ & 0.529 & 0.539 & 0.530 & 0.526 & 0.508 \\
\hline $\mathbf{1 . 0}$ & 0.520 & 0.545 & 0.528 & 0.528 & 0.523 \\
\hline $\mathbf{1 . 2}$ & 0.338 & 0.377 & 0.250 & 0.154 & 0.241 \\
\hline
\end{tabular}

From (Table 2), $1 \mathrm{ml}$ of $1 \% \mathrm{NaNO}_{2}$ has been selected with one minute as a reaction time.

\section{Effect of sulphamic acid amount with time}

Between $0.3-1.5 \mathrm{ml}$ of $3 \%$ of sulphamic acid solution was added, and absorbance of the solutions was followed at different standing time.

Table 3: Effect of sulphamic acid amount with time

\begin{tabular}{|c|c|c|c|c|c|}
\hline \multirow{2}{*}{$\begin{array}{c}\text { ml of sulphamic acid } \\
\text { ( 3\% ) solution }\end{array}$} & \multicolumn{5}{|c|}{ Absorbance/minute standing time with shaking } \\
\cline { 2 - 5 } & $\mathbf{1}$ & $\mathbf{2}$ & $\mathbf{3}$ & $\mathbf{5}$ & $\mathbf{7}$ \\
\hline $\mathbf{0 . 3}$ & 0.041 & 0.129 & 0.115 & 0.112 & 0.102 \\
\hline $\mathbf{0 . 5}$ & 0.526 & 0.544 & 0.495 & 0.413 & 0.339 \\
\hline $\mathbf{0 . 7}$ & 0.472 & 0.514 & 0.493 & 0.413 & 0.335 \\
\hline $\mathbf{1 . 0}$ & 0.420 & 0.453 & 0.455 & 0.405 & 0.330 \\
\hline $\mathbf{1 . 2}$ & 0.395 & 0.445 & 0.406 & 0.368 & 0.327 \\
\hline $\mathbf{1 . 5}$ & 0.361 & 0.392 & 0.353 & 0.352 & 0.343 \\
\hline
\end{tabular}

From (Table 3) $0.5 \mathrm{ml}$ of $3 \%$ of sulphamic acid solution was selected with standing time two minute.

\section{Effect of diazotized agent amount}

Effect of (1-5) ml of $\left(2 \times 10^{-3}\right)$ M PABA has been studied against $50-200 \mu \mathrm{g}$ of mNap $/ 20 \mathrm{ml}$ and the determination coefficient of a measured absorbance has been evaluated. (Table 4) shows that $2 \mathrm{ml}$ of diazotized agent solution gave the best result.

Table 4: Effect of diazotized agent amount

\begin{tabular}{|c|c|c|c|c|c|c|}
\hline \multirow{2}{*}{$\begin{array}{c}\text { ml of PABA } \\
\left(2 \times 10^{-3}\right) \mathrm{M}\end{array}$} & \multicolumn{5}{|c|}{ Absorbance/ $\mu \mathrm{g}$ of mNap } & \multirow{2}{*}{$\mathbf{R}^{2}$} \\
\hline & 50 & 70 & 100 & 150 & 200 & \\
\hline 1 & 0.252 & 0.358 & 0.521 & 0.746 & 1.016 & 0.9989 \\
\hline 2 & 0.275 & 0.368 & 0.542 & 0.781 & 1.06 & 0.9991 \\
\hline 3 & 0.243 & 0.351 & 0.498 & 0.744 & 1.03 & 0.9990 \\
\hline 4 & 0.237 & 0.349 & 0.478 & 0.738 & 1.01 & 0.9989 \\
\hline 5 & 0.229 & 0.321 & 0.452 & 0.731 & 0.998 & 0.9982 \\
\hline
\end{tabular}




\section{Selection of base and its amount}

Four types of bases or basic salts at different volumes (1-5) $\mathrm{ml}$ of each have been tasted for their effect on the absorption intensity of the dye formed. The results are listed in (Table 5).

Table 5: Selection of base and its amount

\begin{tabular}{|c|c|c|c|c|c|}
\hline \multirow{2}{*}{$\begin{array}{c}\text { Base used } \\
(\mathbf{1 M})\end{array}$} & $\mathbf{1}$ & $\mathbf{2}$ & $\mathbf{3}$ & $\mathbf{4}$ & $\mathbf{5}$ \\
\cline { 2 - 6 } & $\mathbf{1}$ & 0.544 & 0.280 & 0.237 & 0.189 \\
\hline $\mathbf{N a O H}$ & 0.091 & 0.323 & 0.104 & 0.051 & 0.027 \\
\hline $\mathrm{NaH}_{2} \mathbf{C O}_{3}$ & 0.109 & 0.540 & 0.432 & 0.108 & 0.078 \\
\hline $\mathbf{N a H C O}_{3}$ & 0.078 & 0.158 & 0.548 & 0.537 & 0.124 \\
\hline
\end{tabular}

From (Table 5) $2 \mathrm{ml}$ of sodium hydroxide solution (1M) has been selected.

\section{Effect of surfactant}

In order to study the effect of surfactants on absorption intensity, $2 \mathrm{ml}$ of anionic [sodium dodecyl sulphate (SDS)], cationic [cetylpyridinium chloride (CPC)], [cetyltrimethylammonium bromide (CTAB)] surfactants with different order of additions were followed (Table 6).

\section{Table 6: Effect of surfactants}

\begin{tabular}{|c|c|c|c|c|c|c|}
\hline \multirow{2}{*}{$\begin{array}{l}\text { Surfactant solution } \\
\left(1 \times 10^{-3} \mathrm{M}\right) \\
\end{array}$} & \multicolumn{6}{|c|}{ Absorbance/order* of addition } \\
\hline & I & II & III & IV & $\mathbf{V}$ & VI \\
\hline SDS & 0.500 & 0.508 & 0.519 & 0.518 & 0.520 & 0.519 \\
\hline СТАВ & 0.303 & 0.312 & 0.316 & 0.311 & 0.312 & 0.312 \\
\hline CPC & 0.342 & 0.351 & 0.348 & 0.344 & 0.345 & 0.344 \\
\hline
\end{tabular}

Not: Absorbance without surfactant $=0.542$

* I. p-aminobenzoic acid (PABA) + surfactant (S) $+\mathrm{H}_{3} \mathrm{PO}_{4}(\mathrm{H})+\mathrm{NaNO}_{2}(\mathrm{~N})+$ Sulphamic acid (F) + mNaproxen(D) $+\mathrm{NaOH}(\mathrm{B})$
II. $\mathrm{PABA}+\mathrm{H}+\mathrm{S}+\mathrm{N}+\mathrm{F}+\mathrm{D}+\mathrm{B}$
III. $\mathrm{PABA}+\mathrm{H}+\mathrm{N}+\mathrm{S}+\mathrm{F}+\mathrm{D}+\mathrm{B}$
IV. $\mathrm{PABA}+\mathrm{H}+\mathrm{N}+\mathrm{F}+\mathrm{S}+\mathrm{D}+\mathrm{B}$
V. $\mathrm{PABA}+\mathrm{H}+\mathrm{N}+\mathrm{F}+\mathrm{D}+\mathrm{S}+\mathrm{B}$
VI. $\mathrm{PABA}+\mathrm{H}+\mathrm{N}+\mathrm{F}+\mathrm{D}+\mathrm{B}+\mathrm{S}$

From (Table 6), there is no enhancement in absorbance value, therefor the reaction is followed without addition of surfactant.

\section{Stability of reaction}

The Stability of the colored product against time has been followed using $100 \mu \mathrm{g} \cdot \mathrm{ml}^{-1}$ of mNap.

Table 7: Stability of the colored product

\begin{tabular}{|c|c|c|c|c|c|c|c|c|c|c|c|c|}
\hline $\begin{array}{c}\text { Hg of } \\
\mathbf{m N a p} \\
\mathbf{m l}\end{array}$ & \multicolumn{10}{c|}{ Absorbance/min } \\
\cline { 2 - 13 } & $\mathbf{0}$ & $\mathbf{1}$ & $\mathbf{5}$ & $\mathbf{1 0}$ & $\mathbf{1 5}$ & $\mathbf{2 0}$ & $\mathbf{2 5}$ & $\mathbf{3 0}$ & $\mathbf{3 5}$ & $\mathbf{4 5}$ & $\mathbf{5 0}$ & $\mathbf{6 0}$ \\
\hline 100 & 0.522 & 0.542 & 0.545 & 0.545 & 0.543 & 0.541 & 0.539 & 0.537 & 0.534 & 0.528 & 0.524 & 0.511 \\
\hline
\end{tabular}

(Table 7) indicate that the colored product is stable at least for 60 minute. 


\section{Absorption Spectrum}

Under the optimum reaction conditions, the absorption spectrum of the colored product against blank Fig. (2) shows that wavelength of maximum absorption intensity is $500 \mathrm{~nm}$.this wavelength has been used in subsequent investigations.

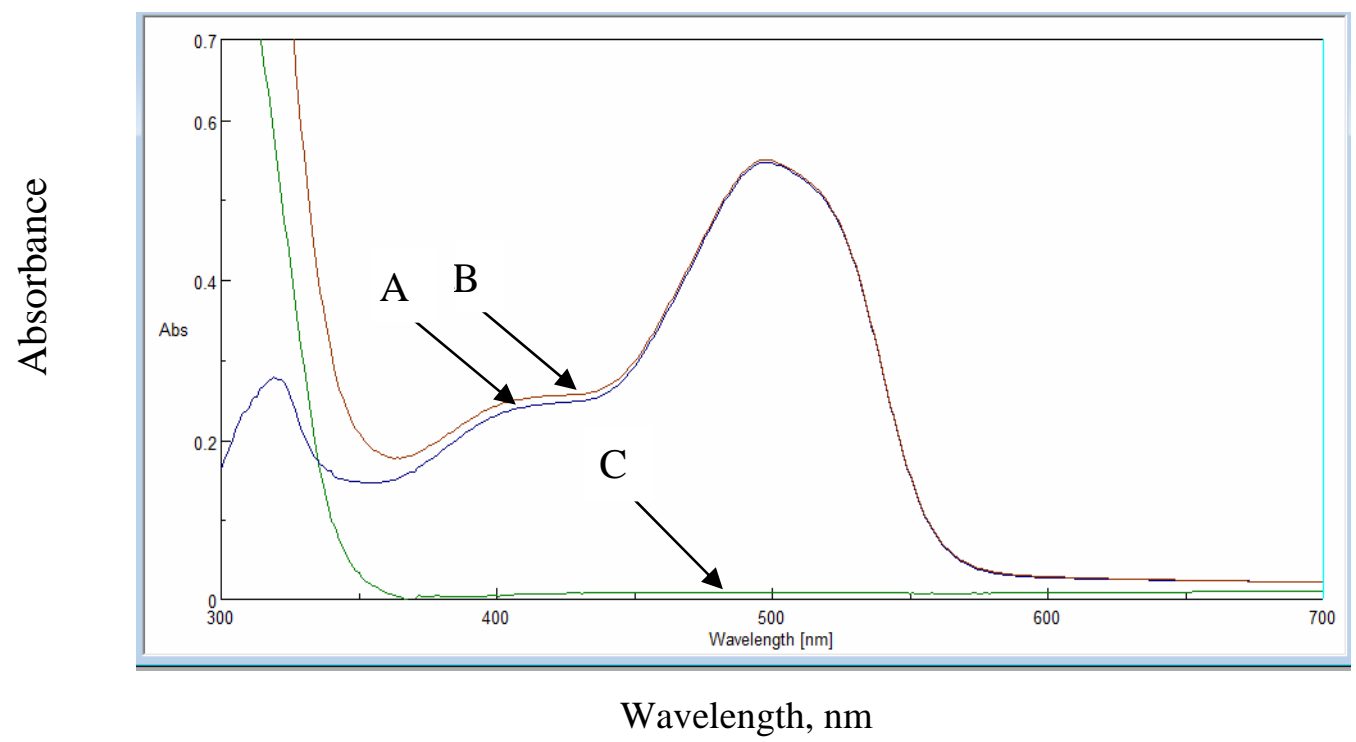

Fig. 2: Absorption spectrum of $100 \mu \mathrm{g} / 20 \mathrm{ml}$ of mNap measured (A) sample against blank (B) sample against distilled water and $(\mathrm{C})$ blank against distilled water

\section{Accuracy and precision}

To check the accuracy and precision of the calibration graph, mNap is determined at three different concentrations; the results are shown in (Table 8), which indicates good accuracy and precision.

Table 8: Accuracy and precision

\begin{tabular}{|c|c|c|}
\hline $\begin{array}{c}\text { Amount mNap taken } \\
\mathbf{\mu g} / \mathbf{2 0} \mathbf{~ m l}\end{array}$ & $\begin{array}{c}\text { Relative standard } \\
\text { deviation } \mathbf{\%}^{*}\end{array}$ & Relative error $\mathbf{\%}^{*}$ \\
\hline 50 & \pm 2.65 & 1.74 \\
\hline 100 & \pm 1.93 & 0.43 \\
\hline 200 & \pm 0.66 & -0.10 \\
\hline
\end{tabular}

* Average of five determinations.

\section{Nature of the Dye}

The composition of the intense orange azo dye has been established using Job's method and mole -ratio method.The results show that both methods confirm the presence of 1:1 azo dye of probably the following structure:<smiles>CC(C(=O)O)c1ccc2cc(O)c(/N=N/c3ccc(C(=O)O)cc3)cc2c1</smiles>

The suggested structure of the orange azo dye 


\section{Stability constant}

The conditional stability constant of the formed azo dye in aqueous solution is estimated and found to be $1.1 \times 10^{4} \mathrm{l} . \mathrm{mol}^{-1}$. The results of estimation are given in (Table 9).

Table 9: Stability constant

\begin{tabular}{|c|c|c|c|c|}
\hline \multirow{2}{*}{$\begin{array}{c}\text { ml of mNAP } \\
\left(\mathbf{2 \times 1 0 ^ { - 3 }} \mathbf{M}\right)\end{array}$} & $\mathbf{A}_{\mathbf{s}}{ }^{*}$ & $\mathbf{A}_{\mathbf{m}}{ }^{* *}$ & $\alpha^{* * *}$ & $\begin{array}{c}\text { K } \\
\mathbf{1 . m o l}^{\mathbf{- 1}} \mathbf{)}\end{array}$ \\
\hline $\mathbf{0 . 5}$ & 0.827 & 1.086 & 0.238 & $1.3 \times 10^{4}$ \\
\hline $\mathbf{1 . 0}$ & 1.662 & 2.113 & 0.213 & $8.6 \times 10^{3}$ \\
\hline
\end{tabular}

*Absorbance of the same amount of sample and reagent (1 sample:1 reagent)

**Absorbance of a maximum amount of reagent (1 sample:10 reagent)

*** Ratio of dissociation $\left(\alpha=\mathrm{A}_{\mathrm{m}}-\mathrm{A}_{\mathrm{s}} / \mathrm{A}_{\mathrm{s}}\right)$

\section{Effect of organic solvents}

The spectrophotometric characteristic of the colored product is more detectable using acetic acid but water is still being the choice because of its availability and low cost .

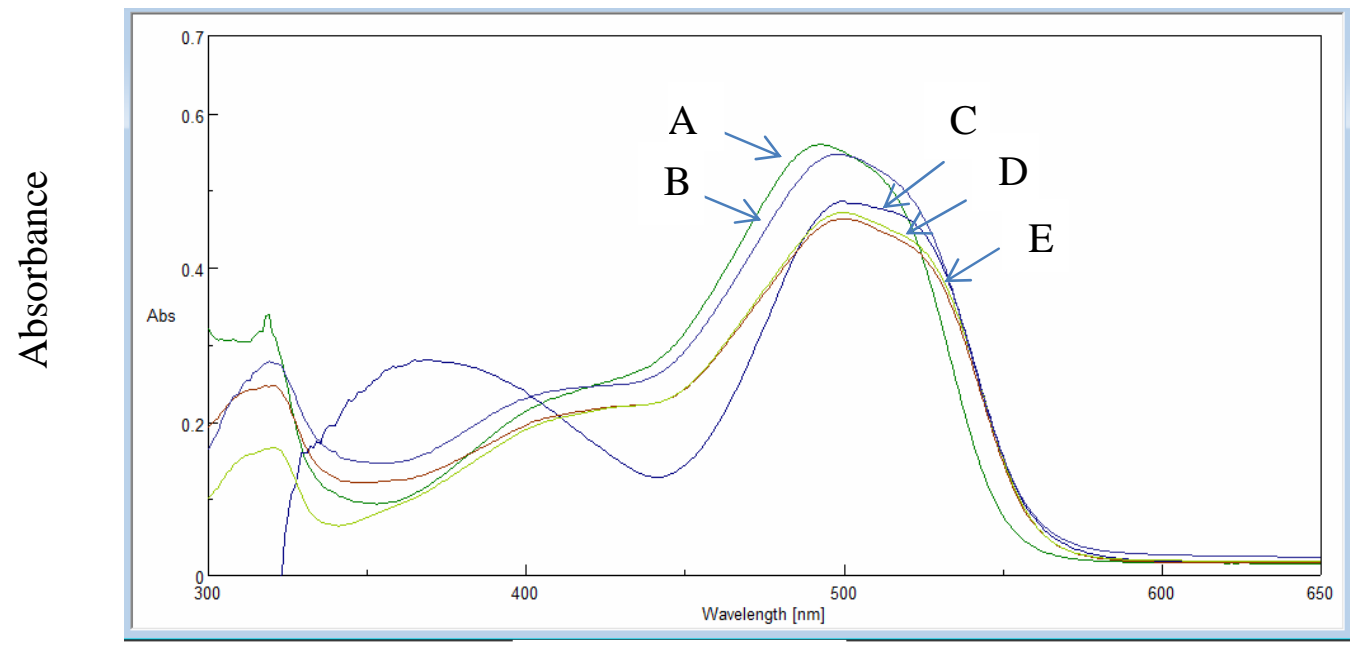

Wavelength, nm

Fig. 3: Effect of solvents
A: Acetic acid
B: Acetone
C: n-Propanol
D: Ethanol
E: Water

\section{Effect of interferences}

In order to realize the analytical application of this method ,effect of foreign compounds have been studied by carrying out the determination of $100 \mu \mathrm{g}$ of mNap in the presence of 100, 300, $500,1000 \mu \mathrm{g}$ of foreign compounds using the recommended procedure. The result are shown in (Table 10).

\section{Table 10: Effect of interferences}

\begin{tabular}{|c|c|c|c|c|}
\hline \multirow{2}{*}{ Interferences } & \multicolumn{4}{|c|}{ Recovery / / g of Interferences } \\
\cline { 2 - 5 } & $\mathbf{1 0 0}$ & $\mathbf{3 0 0}$ & $\mathbf{5 0 0}$ & $\mathbf{1 0 0 0}$ \\
\hline Starch & 98.15 & 97.12 & 99.85 & 97.94 \\
\hline Glucose & 98.76 & 96.06 & 96.71 & 96.71 \\
\hline Gum Arabic & 94.66 & 93.63 & 91.99 & 93.02 \\
\hline Lactose & 100.0 & 100.2 & 95.68 & 97.33 \\
\hline
\end{tabular}




\section{Application of the method}

To test the applicability of the present method, it has been applied to the determination of Nap in pharmaceutical preparations. The results are listed in (Table 11) indicating a good applicability of the method.

Table 11: application of the method

\begin{tabular}{|c|c|c|c|}
\hline \multirow{2}{*}{$\begin{array}{c}\text { Amount of } \mathbf{~ m N a p ~ / 2 0} \\
\mathbf{m l}\end{array}$} & \multicolumn{3}{|c|}{ Recovery * (\%) of NAP } \\
\cline { 2 - 4 } & $\begin{array}{c}\text { Naproxen (tablet 500 } \\
\text { mg) -Inaprolfort, } \\
\text { Bilim, Turky }\end{array}$ & $\begin{array}{c}\text { Naproxen (tablet } \\
\mathbf{5 0 0} \text { mg)-S.D.I, } \\
\text { Iraq }\end{array}$ & $\begin{array}{c}\text { Naprox (tablet 500mg) - } \\
\text { Medical Bahri Company, } \\
\text { Damascus -Syria }\end{array}$ \\
\hline 50 & 97.8 & 95.9 & 96.7 \\
\hline 100 & 98.2 & 96.3 & 99.5 \\
\hline 200 & 100.0 & 96.9 & 102.0 \\
\hline
\end{tabular}

*Average of three determinations.

\section{t-test}

Both the present method and British Pharmacopeia method (British Pharmacopeia, 2013) has been applied at the same time to t-test calculation (Christian, 2004) and the value compared with statistical tables for four degree of freedom at 95\% validation level. The result in Table (12) show that there is no a real difference between the two methods.

Table 12:T-test

\begin{tabular}{|c|c|c|c|}
\hline \multirow{2}{*}{ Drug } & \multicolumn{2}{|c|}{ Recovery * \% } & \multirow{2}{*}{ t-exp } \\
\cline { 2 - 3 } & Present method & British Pharmacopeia method & 1.49 \\
\hline $\begin{array}{c}\text { Naproxen (tablet 500 mg)- } \\
\text { Inaprolfort,Bilim,Turky }\end{array}$ & 98.7 & 99.9 & -1.03 \\
\hline $\begin{array}{c}\text { Naprox (tablet 500mg) -Medical } \\
\text { Bahri Company, Damascus -Syria }\end{array}$ & 99.4 & 97.4 & \\
\hline
\end{tabular}

- Average of three determinations.

\section{REFERENCES}

Acomoffat, O.M.D.; Widdop, B. (2005). "Clarke's Analysis of Drugs and Poisons. CD ROM.

Al-Hamdany, F.K. (2009). Synthesis of some (s)-2-(6'-methoxy-2'-naphthyl) propanoic acid derivatives (Naproxen). Ph. D. thesis, university of Mosul, pp. 39-62.

Alhazmi, H.A.; Al Brattey, M. (2017). Conductometric determination of Naproxen in bulk and pharmaceutical dosage form). European J. Chem. , 8(4),339-343

Alizadeh, N.; Keyhanian, F. (2015). Simple, sensitive and selective spectrophotometric assay of naproxen in pure ,pharmaceutical preparation and human serum samples. Acta Poloniae Pharmaceutica-Drug Research, 72(5), 867-875.

British Pharmacopeia. (2013). "System Simulation Ltd the Stationary Office". Londone, $7^{\text {th }}$ ed., CD ROM.

Christian, G.D. (2004). "Analytical Chemistry". $6^{\text {th }}$ ed., John Wiley and Sons, Inc., New York, 90p.

Idowu, S.O.; Adegoke, O.A.; Adeniji, A.O.; Olaniyi, A.A. (2009). Colorimetric assay of naproxen tablets by derivatization using 4-carbonyl-2,6-dinitrobenzene diazonium ion. East and Central African J. Pharmaceutical Sci., 12(1), 8-14.

Jain, N.A.; Lohiya, R.T.; Umekar, M.J. (2011). Spectrophotometric determination of naproxen and esomeprazole in a laboratory mixture by Simultaneous equation, absorption correction, absorption ratio and area under curve methods. Intern. J. Pharm. Sci. Res., 2(5), 130-134. 
Karch, A.M. (2010). "Lippincott's Nursing Drug Guide". Lippincott Williams and Wilkins, New York, 834 p.

Keyhanian, F.; Alizadeh, N.; Shojaie, A.F. (2014). Spectrophotometric determination of naproxen as ion -pair with bromophenol blue in bulk, pharmaceutical human serum samples. Current Chem. Letters , 3,15-22.

Lejal, N.; Tarus, B.; Bouguyon, E.; Chenavas, S.; Bertho, N.; Delmas, B.; Ruigrok, R.W.; Di Primo, C.; Slama, A. (2013). Structure based discovery of the novel antiviral properties of naproxen against the nucleoprotein of influenza a virus. Antimicrobial Agents and Chem.,57(5), 31-42.

Lenik, J.; Dumkiewick, R.; Wardak, C.; Marczewska, B. (2002). Naproxen ion-selective electrode and its application to pharmaceutical analysis. Acta Poloniae Pharmaceutica -Drug Research , 59(3), 171-176.

Maheshwari, R.K.; Lakkadwala, S.; Vyas, R.; Ghode, P. (2010). Spectrophotometric determination of naproxen tablets usingniacinamide as hydrotropic solubilizing additives. J. Current Pharmaceutical Research, 4,11-14.

Muneer, S.; Muhammad, I. N.; Abrar, M.A.; Munir, I.; Kaukab, I.; Sagheer, A.; Zafar, H.; Sultana, K. (2017). High performance liquid chromatographic determination of naproxen in prepared pharmaceutical dosage form and human plasma and its application to pharmacokinetic study. J. Chromatogr. Sep. Tech, 8(3), 1-5.

Nijhu, R.S.; Jhanker, Y.M.; Sutradhar, K.B. (2011). Development of an assay method for simultaneous determination of ciprofloxacin and naproxen by uv spectrophotometric method. Stamford J. Pharm. Sci., 4(1),84-90.

Pansara, H.V.; Kakadiya, M.; Saishivam, (2013). Development and validation of RP-HPLC method for simultaneous estimation of naproxen and paracetamol in their combined solid dosage form. Inter. J., 1(7), 633-636.

Sloka, S.N.; Gurupadayya, B.M.; Kumar, Ch.A. (2011). Simultaneous Spectrophotometric determination of naproxen and Pantoprazole in pharmaceuticals dosage form. J. Appl. Chem. Res., 17,65-74.

Soltani, N.; Tavakkoli, N.; Mosavimanesh, Z.S.; Davar, F. (2018). Electrochemical determination of naproxen in the presence of acetaminophen using a carbon paste electrode modified with activated carbon nanoparticles, Comptes. Rendus. Chem., 21(1),54-60.

Tashtoush, B.M.; Al-Taani, B.M. (2003). HPLC determination of naproxen in plasma, Inter. J. Pharm. Sci., 58(9),614-615.

Veeragoni, A.K.; Sindgi, V.M.; Satla, S.R. (2016). Bioanalytical validated LC-MS method for determination of naproxen in human plasma. International J. for Modern Trends in Sci. and Technol., 2(9), 96-99

Wahbi, AM.; Mabrouk, M.; Moneeb, M.; Kamal, A.H. (2009). Simultaneous determination of the two non-steroidal anti-inflammatory drugs; diflunisal and naproxen in their tablets by chemometric spectrophotometry and HPLC. Pak. J. Pharm. Sci., 22(1), 8-17.

WWW.cpp.edu,chem319=isolation of naproxen ;/files/classes=/424/lab info and exps KaLe; proje.

Yinhuan, Li.; Jiuru, Lu. (2006). Flow injection chemiluminescence determination of naproxen based on $\mathrm{KMnO}_{4}-\mathrm{Na}_{2} \mathrm{CO}_{3}$ reaction in neutral aqueous medium, Anal. Chem. Acta., 577(1),107-110. 